\title{
CORRELATION BETWEEN PERCENTAGE OF BODY FAT WITH SPEED AND CARDIORESPIRATORY ENDURANCE AMONG FUTSAL ATHLETES IN SURABAYA
}

\author{
Cici Damayanti ${ }^{*}$, Merryana Adriani ${ }^{2}$ \\ ${ }^{1-2}$ Department of Nutrition, Faculty of Public Health, Universitas Airlangga, Indonesia \\ *Email: cici.damayanti-2015@fkm.unair.ac.id
}

\begin{abstract}
Futsal is one of the sport that begin to be popular in Indonesia. Physical condition in futsal is an important aspect because it directly affects athlete performance especially for speed and cardiorespiratory. One of the factor that affect physical condition is percentage of body fat. The purpose of this study is to analyze the correlation between percent body fat with physical condition of futsal athletes in Surabaya. This study was an observational analytic study with cross sectional design. The population were sixty-eight peoples from members of Buana Mas FC, Garuda Emas FC, Nisrina FC and Surabaya Porprov team 2019. Fifty-four peoples were selected as subject of this study by proportional random sampling method. Data collection included questionnaires for respondent characteristics namely age, occupation, education, smoking history and sports activity, and then, measurement of subcutaneous fat thickness using skinfold calliper, and measuring speed and cardiorespiratory endurance using sprint $20 \mathrm{~m}$ and yoyo test. Data analyze used Spearman correlation test. The result of this study showed most of respondent have normal percentage of body fat (59.3\%). Respondents speed mostly classified as lacking (50.0\%) and cardiorespiratory endurance respondents mostly classified as sufficient $(59.3 \%)$. The results showed an positive correlation $(\mathrm{p}=0.001 ; \mathrm{R}=0.732)$ between percent body fat with speed, it was mean that the higher percentage of body fat, the slower sprint time. And there was negative correlation ( $\mathrm{p}=0.001 ; \mathrm{R}=-0.639)$ between percentage of body fat and cardiorespiratory endurance, so the higher percentage of body fat, the lower cardiorespiratory endurance. This contradictory conclusion is due to increasing sprint time, the respondent speed will decrease while $\mathrm{V}_{2} \mathrm{Max}$ increase so the cardiorespiratory endurance will increase.
\end{abstract}

Keywords: body fat percentage, speed, cardiorespiratory endurance, futsal

\section{INTRODUCTION}

Since 2003, futsal has become a sport that has been starting to be in great demand in Indonesia. The sport of futsal began to be developed from Uruguay in 1930 (Bichescu, 2014). Indonesia's achievements at the Asian level are still not encouraging. The Indonesian Futsal National Team has played 14 times in the AFF championship but won the title only in 2010. In the last 5 years, namely 2013-2018, Indonesia's best achievement was only winning 3rd place in 2018. In 2016 and 2017 Indonesia failed in the preliminary round. One of the competitions held in Indonesia is the Indonesian Professional Futsal League which has been held since 2006 which brings together the best futsal teams from all over Indonesia. East Java participated in the competition from 2010-2018 but was only able to reach third place in 2017.

This declining performance in futsal can be improved by optimizing the physical condition of the players. In the category of achievement sports, physical condition is an important aspect because it directly impacts athletes' performance (Joshua, 2017). Physical conditions that are more dominant in futsal are speed and endurance of the heart and lungs. Speed plays a role in playing short passes, breakthrough passes and anticipating opponents in counterattacking with fast movements (Pradipta, 2017). Cardiac pulmonary endurance is the maximum capacity of the heart to breathe in oxygen or called VO2 max. The results showed that athletes who have a maximum $\mathrm{VO} 2$ of $80 \mathrm{~mL} /$ $\mathrm{kg} \mathrm{BW} /$ minute can run $5000 \mathrm{~m}$ faster than athletes with a maximum $\mathrm{VO} 2$ of $40 \mathrm{~mL} / \mathrm{kg} \mathrm{BW} /$ minute (Levine, 2008). The higher the VO2 maximum, the better the cardiovascular endurance so that the performance will be better. In Saichudin (2014), respondents of futsal players had an average $\mathrm{VO} 2$ Max value of $44.27 \mathrm{ml} / \mathrm{kg} \mathrm{BW} /$ minute, the highest result is $55.40 \mathrm{ml} / \mathrm{kg} \mathrm{BW} /$ minute, and the lowest 
result is $38.50 \mathrm{ml} / \mathrm{kg} \mathrm{BW} /$ minute (Abdillah, 2014). Based on the results of this study, it was found that most of the futsal players had low heart-lung endurance. Athletes who do not have a good VO2 Max will experience a decrease in stamina and ability and will make many fundamental mistakes that can be detrimental (Debbian, 2016).

The description above can conclude that physical condition is the basis for achieving achievement. If the tactics and techniques of the players are great but the physical condition is poor, the achievements will be different from those of players who have technical skills, good strategy and are supported by good physical condition. Futsal is a game that requires good physical condition. With the stability of the physical condition, the players will last a long time well during the 2x20 minute futsal game (Maryami, 2016).

Factors that can affect athlete's performance other than physical condition are the athlete's body composition (Setiowati, 2014). The composition of the human body consists of $60 \%$ percent fluid and $40 \%$ solids which can give shape to a person's body proportions consisting of muscle, bone, fat and other tissues (Corwin, 2009). Percent body fat is generally used to determine optimal body composition in athletes. The measurement of body fat percentage is done by measuring the thickness of the subcutaneous or subcutaneous fat. The mass of body fat is spread over the subcutaneous area more than $50 \%$, around the internal organs there is $45 \%$ or what is commonly called visceral fat and the rest is scattered in the intramuscular tissue (Almatsier, 2011).

Body fat percentage is considered equally important for maximizing athlete potential. Several studies have found a negative correlation between body fat percentage and body performance, the higher the body fat percentage, the lower the performance. In Anwar (2016), it is known that there is a relationship between the percentage of body fat and the running speed of football players $(r=0.59 ; p=0.001)$. The higher the body fat percentage, the longer the running time increases. In addition, there was a significant relationship between the percent of body fat and the heart-lung endurance of soccer players $(r=-0.4 ; p=0.004)$. The higher the body fat percentage, the lower the
VO2Max value. The results of Sulaiman's (2011) research on national futsal players in Malaysia showed that the average percentage of body fat in futsal players was $18.33 \%$ with the highest yield of $36.95 \%$ and the lowest result of $10.82 \%$. Based on these results, it was found that most futsal players had excess body fat percent. If the athlete's excess body fat percentage will affect the cardiovascular system, body composition, endurance of muscles, strength of muscles, and flexibility (Truter, 2010). If the athlete is unable to maintain body proportions and composition, the opportunity is to be overweight and even obese (Kreider, 2010).

From the interviews with researchers to several coaches from the futsal team, the athlete's body composition was not given too much attention because the coach only focused on training and playing strategies. Based on the explanation that has been mentioned, the researcher wanted to examine the body composition of futsal athletes and its relationship with the physical condition of the futsal athletes.

\section{METHODS}

This study employed a cross-sectional research design and was a quantitative research that was analytic observational. This research was conducted in two different places, namely the Nisrina Futsal Field and Gool Futsal Universitas 17 August 1945. The study was conducted in April-May 2019. The population in this study were members who were members of the Buana Mas FC team, Garuda Emas FC, at least 6 months. Nisrina FC and the Surabaya 2019 Porprov Team with a total of 68 athletes. The sample size was obtained using Lemeshow's (1997) calculation of 54 samples. The sampling technique used was proportional random sampling which then calculated the number of samples to be used for each team. From the calculation results obtained a sample of 14 athletes from Buana Mas FC, 10 athletes from the Surabaya 2019 Porprov Team and each of 15 athletes from Buana Mas FC and Nisrina FC. After obtaining the number of samples for each team, members of the team will be randomly selected according to the maximum number of samples and selected according to the inclusion criteria. The sample inclusion criteria are 
members of the futsal team in Surabaya who have joined for at least 6 months, often participate in routine training at least 2 (two) times a week, are 18-25 years old, are not injured, are willing to be respondents and do a physical condition test.

Percentage of body fat was the independent variable and the dependent variable in the study, namely heart rate and lung endurance. The data collection technique in the study was filling out a general questionnaire for the characteristics of the respondents. Subject characteristics include age, occupation, education, smoking status or history and sports activity. Age was classified into early, middle and late adolescence, then the respondent's occupation was classified into civil servants, private employees, honorary, selfemployed and students. The characteristics of education are classified into Elementary, Junior, Senior High School, or Vocational School and universities. Smoking history was categorized as yes every day, yes sometimes, no but used to every day, no but used to sometimes and never. For the characteristics of sports activities, there were futsal and other sports activities. Subcutaneous fat thickness was then measured on the triceps, biceps, supscapular, and suprailiacs. The measurement of the thickness of the subcutaneous fat of the subject was carried out by the researcher when the subject had not done physical exercise. Measurement of the thickness of the subcutaneous fat was carried out twice and the average value was taken. Measurements were made using the Qiorange digital skinfold caliper in millimeters. Then from the measurement results, calculations were made to determine body density and body fat percentage. The formula for calculating body density using the Durnin and Womersley (1974) formula is $\mathrm{D}=\mathrm{c}+$ $\mathrm{m}(\mathrm{X} 4)$, where $\mathrm{D}$ is the density of the body, and $\mathrm{X} 4$ is the log of the total measurements of triceps, biceps, supscapular and suprailiac. Then from the results of the calculation of body density, the percentage of body fat was calculated using the Siri formula (1961), namely:

$$
\% B F=\left(\frac{4.95}{D} \times 4.50\right) \times 100
$$

The results of the calculation of body fat percentage were then categorized based on
Jeukendrup (2004) for the categories of soccer or futsal athletes to be less $(<10 \%)$, normal $(10-18 \%)$ and excess (>18\%).

The measurement of speed uses the sprint method or 20 meter run which was done by the respondent running as fast as possible at a distance of 20 meters. Measurements were taken 2 times and the best results were taken. Then the results will be categorized as less ( $>3.44$ seconds), sufficient (2.71-3.44 seconds) and good $(<2.77$ seconds) according to the cut-off from EA Sports BCSPL Fitness Testing (2012). Measurements with this method have tested the validity and got a value of 0.956 and the reliability test got a value of 0.924 (Fuziyono, 2013).

Meanwhile, the measurement of cardiac and pulmonary endurance used the yo-yo test method which was carried out by providing an area of 25 meters with details of 5 meters from cone A to $\mathrm{B}$ for resting and 20 meters from cone B to $\mathrm{C}$ to run according to the rhythm of the beep. The respondent would run to the rhythm until the respondent reached the maximum limit and could not run to the rhythm. Measurements were carried out once and then the results were categorized as very good, good, moderate, moderate, lacking and very poor. The measurement results were in the form of speed level and level from the shuttle which were then converted into VO2Max using the Yoyo Test Reference Table. This method has been tested for validity and reliability and obtained values of 0.968 and 0.996 (Akbar, 2015). The researchers and the coach of each team measured the heart and lung speed and endurance.

The data was tested for normality first using the Kolmogorov-Smirnov method. The results of this study were analyzed using descriptive analysis to provide an overview of the characteristics of the respondents. Then performed inferential statistical analysis using the Spearman correlation test to analyze the relationship between the independent variable and the dependent variable with a $p$-value less than the significance value $(p<0.05)$, which means that there is a relationship between variables. This study passed ethics and obtained a certificate of ethics testing from the Faculty of Public Health, Airlangga University with a code of ethics certificate 141-KEPK. 


\section{RESULT AND DISCUSSION}

Characteristics of respondents in the study including age, gender, occupation, education, status or history of smoking and sports activities are presented in Table 1. Based on table 1.From 54 respondents, most of the respondents $(72.2 \%)$ were classified as late adolescents aged 18- 21 years. Most of the students $(81.5 \%)$ and were SMA / SMK students (98.1\%). Respondents who were mostly classified as adolescents generally experience changes in the proportion of body composition with an increase in muscle mass due to the hormone testosterone which plays a role in protein synthesis. In addition, cardiac physiology changes to a greater extent in adolescents and results in increased cardiac output which can increase cardiovascular endurance (Arum, 2014). Age 17-21 years in men is the peak VO2Max. In another study, the speed and explosive power of the leg muscles when jumping on two big football teams continued to increase at the age of 16-17 years. Athletes less than 17 years of age have a lower percentage of body fat than adults (Joshua, 2017).

There were still $7.4 \%$ of athletes who smoke every day and $24.1 \%$ who smoke occasionally, both classified as active smokers. In smokers, the oxygen supply that enters the body will decrease because the hemoglobin that binds to carbon monoxide is more than oxygen, so that smokers who exercise usually quickly experience fatigue and gasp for breath to meet the oxygen needs needed by the body (Zuhdi, 2017). Someone who has a smoking habit, the maximum volume of oxygen will be lower than someone who does not smoke.

In table 2, it is found that the respondents did futsal activity 2-3 times a week and were classified as sufficient with a duration of 1-2 hours. Apart
Table 1. Distribution of Respondent Characteristics Based on Age, Occupation, Education and Smoking History

\begin{tabular}{lrr}
\hline \multicolumn{1}{c}{ Characteristic } & Total & Percent \\
\cline { 2 - 3 } & $\mathbf{n}$ & \% \\
\hline Age & & \\
$\quad$ Late adolescent (18-21 y.o) & 39 & 72.2 \\
Early adult (22-25 y.o) & 15 & 27.8 \\
Occupancy & & \\
Private employee & 9 & 16.7 \\
Self-employed & 1 & 1.9 \\
Students & 44 & 81.5 \\
Education & & \\
Senior High/Vocational School & 53 & 98.1 \\
Universities & 1 & 1.9 \\
Smoking status & & \\
Yes, everyday & 4 & 7.4 \\
Yes, sometimes & 13 & 24.1 \\
No, used everyday & 1 & 1.9 \\
No, used sometimes & 5 & 9.3 \\
Never & 31 & 57.4 \\
\hline
\end{tabular}

from futsal, the respondents also did other sports as shown in Figure 1. The respondents did sports with sufficient frequency, namely 2-3 times a week with a duration of more than two hours. Routine exercise can be done as a physical activity to increase the potential and abilities of athletes. Someone who did physical activity regularly, would increased cardiovascular efficiency and decreased resting heart rate will decrease when did maximum workload. This could make breathing more efficient when breathing slower so that more oxygen reaches the lungs and results in an increase in cardiovascular endurance (Permatasari, 2018).

Based on table 3, it is known that most of the respondents' body fat percentage was classified as normal, namely as much as $59.3 \%$, while $37.0 \%$ of respondents had a body fat percentage that was classified as excess. In Joshua's (2019) research conducted on the Bintang Timur Surabaya futsal

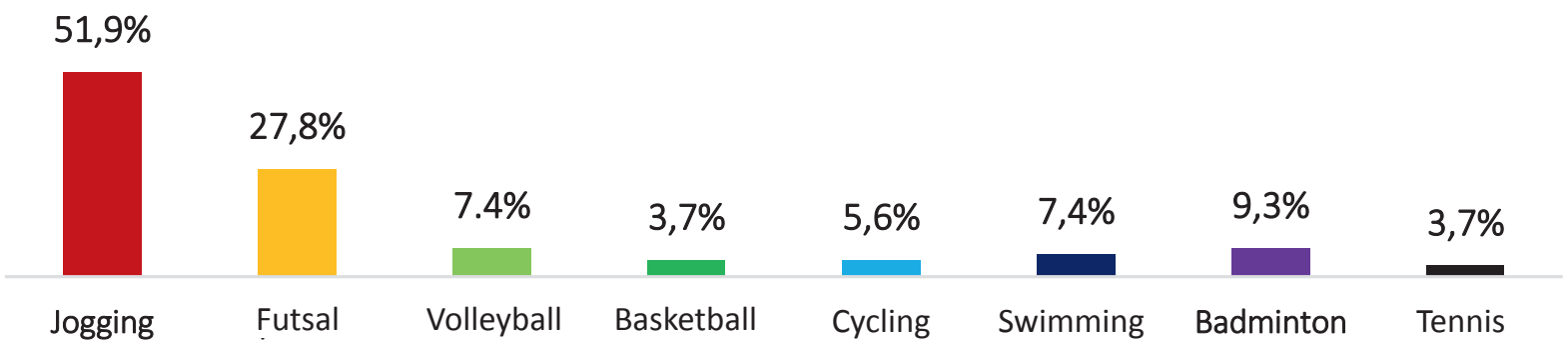

Figure 1. Distribution of Other Sports (Non-futsal) to Futsal Athletes in Surabaya in 2019 
Table 2. Distribution of Respondent Characteristics Based on Sports Activities

\begin{tabular}{lrr}
\hline \multicolumn{1}{c}{ Sport Activities } & n & \% \\
\hline Futsal & & \\
Frequency & & \\
$\quad$ Sufficient $(2-3 \mathrm{x} /$ week $)$ & 49 & 90.7 \\
$\quad$ Often $(>3 \mathrm{x} /$ week) & 5 & 9.3 \\
Duration & & \\
$\quad 20$ minutes $-<1$ hour & 1 & 1.9 \\
1 - $\leq 2$ hours & 53 & 98.1 \\
Other Sport Activities & & \\
Frequency & & \\
$\quad$ Seldom $(\leq 1 \mathrm{x} /$ week) & 17 & 31.5 \\
$\quad$ Sufficient $(2-3 \mathrm{x} /$ week $)$ & 35 & 64.8 \\
$\quad$ Often $(>3 \mathrm{x} /$ week) & 2 & 3.7 \\
Duration & & \\
$\quad<20$ minutes & 11 & 20.4 \\
20 minutes $-<1$ hour & 4 & 7.2 \\
1 - $\leq 2$ hours & 10 & 18.6 \\
$\quad>2$ hours & 29 & 53.8 \\
\hline
\end{tabular}

player, it was known that the average percent of respondents' body fat is proportional or normal (75\%). Futsal athletes must have a body that is quite ideal as seen from the body fat percentage ranging from $10-18 \%$. A balance of muscle mass and fat mass is needed by athletes to achieve the recommended proportion of body size and composition (Maulina, 2015). If an athlete's excess body fat percentage will affect the performance of the cardiovascular system, body composition, muscle endurance, muscle strength, and speed (Truter et al. 2010).

In table 3, the results of the measurement of the running speed of the respondents were mostly classified as less (50\%). In Royana's research (2017), it was found that $50 \%$ of the UPGRIS futsal team players had a relatively low speed. Likewise in Anwar's research (2016) it was also found that the average respondent had a relatively low speed. In futsal, if the player's speed is high, the player will be able to find a gap quickly to provide a counter attack and kick the ball at the goal. Players can anticipate by returning to the defense area quickly so that they can thwart the gap in the opponent's attack in scoring goals (Pradipta et al, 2017).

In table 3, it is known that most of the respondents had sufficient heart-lung resistance, namely $59.3 \%$. This is in line with research by Ulfa, et al. (2017), namely $71.4 \%$ of respondents
Table 3. Distribution of Body Fat Percentage, Heart Lung Speed and Endurance

\begin{tabular}{lcc}
\hline \multicolumn{1}{c}{ Variable } & Total & Percent \\
\cline { 2 - 3 } & $\mathbf{n}$ & $\mathbf{\%}$ \\
\hline Body Fat Percentage & & \\
$(\overline{\mathrm{x}}=17.35 \pm 4.31 \mathrm{SD} ; \min =7.67 ; \max =27.27)$ & \\
$\quad$ Inadequate & 2 & 3.7 \\
$\quad$ Normal & 32 & 59.3 \\
$\quad$ Excessive & 20 & 37.0 \\
Speed & & \\
$(\overline{\mathrm{x}}=3.35 \pm 0.29 \mathrm{SD} ; \min =2.44 ; \max =3.95)$ & \\
$\quad$ Inadequate & 27 & 50.0 \\
$\quad$ Normal & 25 & 46.3 \\
$\quad$ Excessive & 2 & 3.7 \\
Cardiovascular Endurance & \\
$(\overline{\mathrm{x}}=48.67 \pm 1.92 \mathrm{SD} ;$ min $=44.13 ; \max =52.53)$ & \\
$\quad$ Inadequate & 5 & 9.3 \\
$\quad$ Normal & 17 & 31.5 \\
$\quad$ Excessive & 32 & 59.3 \\
\hline
\end{tabular}

who took futsal had moderate or moderate cardiovascular endurance. Cardiac pulmonary endurance is the maximum capacity of the heart to breathe in oxygen or called VO2 max. Respondents with low VO2Max will experience significant fatigue during training so that their mastery of the basic techniques learned during training or competition is not optimal.

\section{Correlation of Body Fat Percentage with Heart Lung Speed and Endurance}

Based on the results of the Spearman analysis test in Table 4, it is known that there was a correlation between the percentage of body fat and the respondent's speed $(p<0.001)$. In Figure 2 , the direction of the correlation between the percentage of body fat (\%) and velocity (seconds) was positive, namely $\mathrm{R}=0.732$. A positive correlation means that the higher the percentage of the respondent's body fat, the more the duration of running the respondent will be. The longer the duration of running required by the respondent, the less the respondent's speed will be. Respondents with a normal body fat percentage mostly had sufficient running speed (71.9\%). Meanwhile, respondents who had an excess percentage of body fat had a relatively low running speed $(100.0 \%)$. Then in Hyka's (2017) study, the results were also obtained, namely that there was a relationship 
between body fat percentage and the speed of football players $(p=0.019)$. The results of this study were also supported by Anwar's (2016) study, where there was a relationship between body fat percentage and the speed of football players $(\mathrm{r}$ $=0.59 ; \mathrm{p}=0.001)$. In Anwar's research (2016) there was a positive correlation result, namely the higher the percentage of body fat of the respondent, the longer the duration of running is so that the respondent's speed tends to be less. In this study, if the percentage of body fat was higher, the duration of the speed would also be longer so that the speed category in running would be less. This can happen because a person's high or excessive body fat only plays a role in increasing body weight and body weight so that it is less profitable for the body. High fat stores cause the body's performance in moving and moving to decrease so that the body's acceleration in running will decrease when the fat in the body was high. Athletes with a low percentage of body fat perform better than athletes with a high percentage of body fat.

In table 4 , it is found that between the percentage of body fat and cardiovascular endurance there is a significant relationship $(p<0.001)$. All respondents with a normal percentage of body fat had sufficient heart-lung resistance. Meanwhile, respondents who had a lower percentage of body fat had less heart and lung resistance. This is supported by research by Anwar (2016), which shows that there was a significant relationship between the percent of body fat and the heart-lung endurance of soccer players $(r=-0.4 ; p=0.004)$. In Sharma's (2015) study, the percentage of body fat was related to cardiovascular endurance $(r=-0.929 ; \mathrm{p}=$
0.046). In Gligoroska's (2015) study, there was a relationship between the percentage of body fat and cardiovascular endurance, even though the relationship is relatively weak $(\mathrm{r}=-0.08 ; \mathrm{p}=$ $0.034)$

The three studies above were also in line with this study, namely that there was a negative relationship between body fat percentage and cardiovascular endurance. Figure 3. shows the negative correlation coefficient (R), which is -0.639 . This means that if the percentage of body fat increases, the heart and lung resistance tends to decrease, and vice versa. The lower the percent result of the respondent's body fat, the better the respondent's heart-lung endurance. Excess body fat will increase a person's body mass resulting in a decrease in movement speed. Excess body fat composition will result in faster fatigue. If the body fat composition is high, there will be an increase in body temperature, so that the body quickly

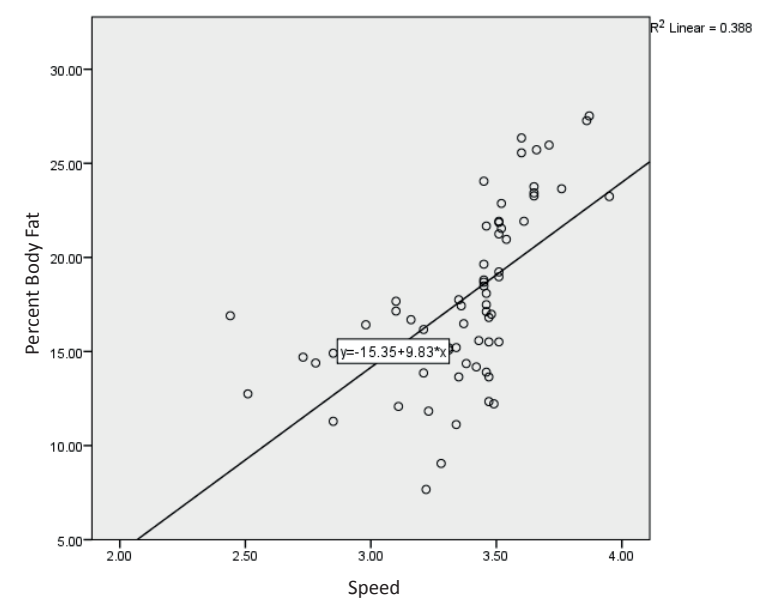

Figure 2. Scatterplot Percent Body Fat by Running Speed

Table 4. Correlation of Body Fat Percentage with Heart Lung Speed and Endurance

\begin{tabular}{|c|c|c|c|c|c|}
\hline \multirow{3}{*}{ Variable } & \multicolumn{3}{|c|}{ Body Fat Percentage } & \multirow{3}{*}{$\begin{array}{l}\text { Total } \\
\text { n (\%) }\end{array}$} & \multirow{3}{*}{ p-value } \\
\hline & Inadequate & Normal & Excessive & & \\
\hline & n (\%) & n (\%) & n (\%) & & \\
\hline \multicolumn{6}{|l|}{ Speed } \\
\hline Inadequate & $0(0.0)$ & $7(21.9)$ & $20(100.0)$ & $27(50.0)$ & \multirow{3}{*}{$0.001 *$} \\
\hline Sufficient & $2(100.0)$ & $23(71.9)$ & $0(0.0)$ & $25(46.3)$ & \\
\hline Good & $0(0.0)$ & $2(6.2)$ & $0(0.0)$ & $2(3.7)$ & \\
\hline \multicolumn{6}{|c|}{ Daya Tahan Jantung Paru } \\
\hline Inadequate & $2(100.0)$ & $0(0.0)$ & $3(15.0)$ & $5(9.3)$ & \multirow{3}{*}{$0.001 *$} \\
\hline Moderate & $0(0.0)$ & $0(0.0)$ & $17(85)$ & $17(31.5)$ & \\
\hline Sufficient & $0(0.0)$ & $32(100.0)$ & $0(0.0)$ & $32(59.3)$ & \\
\hline
\end{tabular}




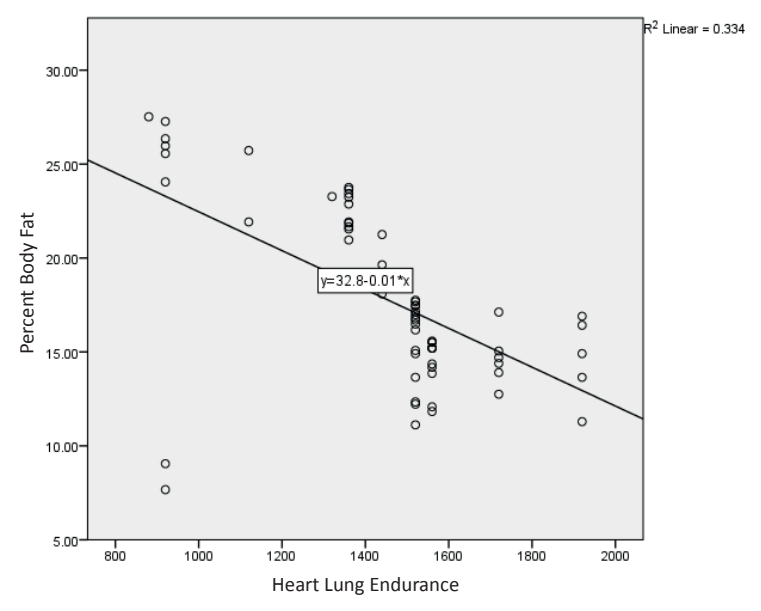

Figure 3. Percent Body Fat Scatterplot with Heart Lung Endurance

experiences fatigue and affects the endurance of an athlete's heart and lungs (Salamah, 2019).

Weight gain due to increased fat reserves will decrease your VO2 max during activity. Excess fat does not benefit the heart in extracting oxygen to the skeletal muscles so that the heart works harder. Large deposits of fat will not be efficient in energy use because they require more oxygen and aggravate one's physical activity (Syantika, 2013). In conditions of high percent body fat, cardiac output will decrease and consequently the amount of blood pumped decreases. This causes oxygen consumption to decrease in working muscles and results in decreased cardiovascular endurance (Manore, 2009).

Increasing body weight results in increased fat reserves in adipose cells and muscle glycogen (Murbawani, 2017). Decreasing body fat will improve the performance of sports athletes because of the improved physical condition. If the percentage of fat is high or increases, the muscle mass will decrease so that the muscles are not optimal in contracting and muscle performance is less effective and efficient (Putranto, 2015). Most of the respondents have sufficient heart and lung resistance due to the fact that the respondents' sports activities are classified as good so that the body is better trained and their physiological conditions improve.

\section{CONCLUSION}

The percentage of body fat with heart-lung speed and endurance in futsal athletes in Surabaya has a significant relationship. Most athletes have normal body fat percentage. Athletes who have a normal body fat percentage mostly have sufficient heart-lung speed and endurance. Increasing the percentage of body fat has a negative impact on physical conditions such as decreased running speed and cardiovascular endurance. A balanced diet and nutritional intake need to be applied to athletes so that there is no excess or deficiency of nutrient intake. Athletes also need to implement regular sports activities to improve their physical condition. This is done to keep the athlete's body fat percentage within the normal range.

\section{ACKNOWLEDGEMENT}

The author would like to thank the coaches and managers of the Buana Mas FC Futsal team, Garuda Emas FC, Nisrina FC and the Surabaya 2019 Porprov Futsal Team who have given permission for athletes to participate and assist in the implementation of the research. The researchers would also like to thank athletes who were willing to be respondents in this study from start to finish. Enumerators who assist in the implementation of research and related parties who contribute to the implementation of the research.

\section{REFERENCES}

Abdillah, F.T., Saichudin, \& Sudjana, I.N. (2014). Survei tingkat volume oksigen maksimal atlet PorProv Kota Batu. Jurnal Sport Science, 4(3), 130-140. Retrieved from http://journal.um.ac.id/ index.php/sport-science/article/view/4919.

Akbar, I.A. (2015). Uji validitas dan reliabilitas yo-yo intermittent recovery test. (Skripsi). Universitas Pendidikan Indonesia.

Almatsier S. (2011). Prinsip Dasar Ilmu Gizi. Jakarta: Gramedia Pustaka Utama.

Anwar, S. \& Noohu, M.M. (2016). Correlation of percentage body fat and muscle mass with anaerobic and aerobic performance in collegiate soccer players. Indian J. Physiol Pharmacol, 60(2), 135-144. Retrieved from https://www. ijpp.com/IJPP\%20archives/2016_60_2/137144.pdf .

Arum, V.M \& Mulyati, T. (2014). Hubungan intensitas latihan, persen lemak tubuh dan kadar hemoglobin dengan ketahanan kardiorespirasi atlet sepak bola. Journal of Nutrition College, 
3(1), 179-183. Retrieved from https://www. ejournal3.undip.ac.id/index.php/jnc/article/ view/4556.

Bichescu, A\& Kiss, Z. (2014). The analysis of futsal in Romania. Journal of Physical Activities, (1), 43-51. Retrieved from https://www.uav.ro/jour/ index.php/ajpa/article/view/32/pdf_2.

Corwin, E.J. (2009). Buku Saku Patofisilogi. Jakarta: Aditya Media.

Debbian, S.R.A. \& Rismayanthi, R.C. (2016). Profil tingkat volume oksigen maksimal dan kadar hemoglobin pada atlet Yongmodo Akademi Militer Magelang. Jurnal Olahraga Prestasi, 12(2), 19-30. Retrieved from https://journal.uny. ac.id/index.php/jorpres/article/view/11874.

EA Sports BCSPL. (2012). Fitness Testing PKG: 2012 Report and SPARQ Protocol. BC Soccer.

Fuziyono, A. (2013). Profil Kondisi Fisik Atlet Sepak Bola SMA Negeri 3 Cimahi. (Skripsi). Universitas Pendidikan Indonesia.

Gligoroska, J.P., Manchevska, S., Efremova, L., Todorovska, L., \& Nikolic, S. (2015). Body composition snd maximal oxygen consumption in adult soccer players in The Republic of Macedonia. Journal of Helath Science, 5(3), 85-92. Retrieved from https://www.jhsci.ba/ojs/ index.php/jhsci/article/view/443.

Hyka, A., Bicoku, E., \& Mysliu, A. (2017). The association of sprint performance with anthropometric parameters in youth soccer players. Sport Mont Journal, 15(1), 31-35. Retrieved from http://www.sportmont.ucg. ac.me/clanci/SM_februar_2017_Hyka.pdf.

Jeukendrup, A.E. \& Gleeson, M. (2004). Sport nutrition: an introduction to energy production and performance. Illinois: Human Kinetics.

Joshua, A. (2017). Evaluasi anthropometri dan kondisi fisik atlet futsal bintang timur Surabaya. Jurnal Prestasi Olahraga, 2(1), 1-11. Retrieved from http://jurnalmahasiswa.unesa.ac.id/ index.php/jurnal-prestasi-olahraga/article/ view/21680.

Kreider, R.B., Wilborn, C.D., Taylor, L., Campbell, B., Almada, A.L., Collins, R., ... Kalman, D.S. (2010). ISSN exercise \& sports nutrition review: research \& recommendations. Journal Sport Nutrition, 15(38), 1-57. Retrieved from https:// jissn.biomedcentral.com/track/pdf/10.1186/ s12970-018-0242-y.

Lemeshow, S. (1997). Besar sampel dalam penelitian kesehatan. Yogyakarta: Gadjahmada University Press.

Levine B.D. (2008). $\mathrm{VO}_{2} \mathrm{Max}$ : what do we know, and what do we still need now? Journal Physiology Society, 586(1), 25-34. Retrieved from http://jp.physoc.org/content/586/1/25.full. pdf + html.

Manore, M.M., Meyer, N.L., \& Thompson, J. (2009). Sport nutrition for health and performance. 2nd Edition. Champaign: Human Kinetics.

Maryami, D. (2016). Profil kondisifisikpemain putih abu-abu futsal Universitas Negeri Yogyakarta (Paf UNY) Menuju Women Pro Futsal League Tahun 2016. (Skripsi). Universitas Negeri Yogyakarta.

Maulina, M. (2015). Profil antropometri dan somatotipe pada atlet bulutangkis. Jurnal Kedokteran dan Kesehatan Malikussaleh, 1(2), 69-74. Retrieved from https://ojs.unimal.ac.id/ index.php/averrous/article/view/413.

Murbawani, E.A. (2017). Hubungan persen lemak tubuh dan aktivitas fisik dengan tingkat kesegaran jasmani remaja putri. Journal of Nutrition and Health, 5(2), 69-84. Retrieved from https://ejournal.undip.ac.id/index.php/ actanutrica/article/view/15351.

Permatasari, F.D., Adi, A.C., \& Dewi, R.D. (2018). Hubungan status gizi dan level aktivitas fisik dengan tingkat kebugaran pada pemain bola basket di ukm basket. Amerta Nutrition, 2(4), 332-339. Retrieved from https://e-journal.unair. ac.id/AMNT/article/view/9603.

Pradipta, G.D., Setyawan, D.,A., Kusumawardhana, B., \& Royana, I.,F. (2017). Analisis Kondisi Fisik PemainTim Futsal Upgris. (Skripsi). Universitas PGRI Semarang.

Putranto, P. (2015). Hubungan antara ketebalan lemak tubuh dengan kondisi fisik atlet karate pelajar putra institute karate-do Indonesia Cabang Kabupaten Semarang Tahun 2015. (Skripsi). Universitas Negeri Semarang.

Royana, I.F. (2017). Analisis kondisi fisik pemain tim futsal UPGRIS. Jendela Olahraga, 2(2), 2-19. Retrieved from http://journal.upgris.ac.id/ index.php/jendelaolahraga/article/view/1860.

Salamah, R., Kartini, A., \& Rahfiludin, M.Z. (2019). Hubungan asupan zat gizi, aktivitas fisik, dan persentase lemak tubuh dengan kebugaran jasmani. Media Kesehatan Masyarakat Indonesia, 18(2), 14-18. Retrieved from https:// ejournal.undip.ac.id/index.php/mkmi/article/ download/23140/1509.

Saputra, R.P.S., Tursilowati, S., Larasati, M. D., Sunarto. (2019). Hubungan asupan lemak, persen lemak tubuh, somatotype dengan kelincahan atlet sepakbola diklat salatiga training centre 
(STC). Jurnal Riset Gizi, 7(1), 21-27. Retrieved from http://ejournal.poltekkes-smg.ac.id/ojs/ index.php/jrg/article/view/4360.

Setiawati, A. (2014). Hubungan indeks massa tubuh, persen lemak tubuh, asupan zat gizi dengan kekuatan otot. Jurnal Media Ilmu Keolahragaan Indonesia, 4(1), 32-38. Retrieved from https://journal.unnes.ac.id/nju/index.php/ miki/article/view/4394.

Sharma, M., Kamal, R.B., \& Chawla, K. (2015). Correlation of body composition to aerobic capacity: a cross sectional study. international journal of apllied research, 2(1), 38-42. Retrieved from http://www.allresearchjournal. com/archives/2016/vol2issue1/PartA/1-13-107. pdf.

Sulaiman, N., Rashid, N.M., Adnan, R., \& Misdan, M. (2011). Body composition of malaysian male futsal players based on playing position. Conference Paper: IEEE Colloquium on Humanities, Science and Enginering. Penang, Malaysia.

Syantika P.Y. (2013). Perbedaan tes balke, tes cooper, dan tes multistage terhadap daya tahan aerobik atlet bola voli Yuso Sleman. (Skripsi). Universitas negeri Yogyakarta.
Truter, L., Pienaar, A.E., Du, \& T.D. (2010). Relationships between overweight, obesity and physical fitness of nine to twelve-year-old south african children. South African Family Practice, 52(3), 227-233. Retrieved from https://www. tandfonline.com/doi/abs/10.1080/20786204.2 010.10873979.

Ulfa, N.A., Widajanti, L., \& Suyatno. (2017). perbedaan status gizi, tingkat konsumsi gizi, aktivitas fisik dan kebugaran jasmani (studi pada siswa ekstrakurikuler pencak silat dan futsal di Sekolah Menengah Kejuruan Teuku Umar Kota Semarang Tahun 2017). Jurnal Kesehatan Masyarakat, 5(4), 714-721. Retrieved from https://ejournal3.undip.ac.id/index.php/jkm/ article/view/18765.

Zuhdi, A.J. \& Yuliastrid, D. (2017). Hubungan kebiasaan merokok terhadap volume oksigen maksimal ( $\left.\mathrm{vo}_{2} \max \right)$ pada mahasiswa jurusan Penkesrek UNESA Angkatan 2015. Jurnal Kesehatan Olahraga, 5(1), 35-42. Retrieved from https://jurnalmahasiswa.unesa.ac.id/ index.php/jurnal-kesehatan-olahraga/article/ view/19532. 